\title{
15. POPULATION DIVERSITY OF PLANKTONIC FORAMINIFERS AND STABLE-ISOTOPE RECORD ACROSS THE EOCENE/OLIGOCENE BOUNDARY: HOLE 549A ${ }^{1}$
}

\author{
Paul Loubere, Department of Geology, Northern Illinois University ${ }^{2}$
}

\begin{abstract}
Eight samples were taken across the Eocene/Oligocene boundary recovered in Hole $549 \mathrm{~A}\left(49^{\circ} 05.28^{\prime} \mathrm{N}, 13^{\circ} 05.88^{\prime} \mathrm{W}\right)$, which is on the continental slope (water depth $2533 \mathrm{~m}$ ) southwest of Ireland in the northeastern Atlantic. The samples were examined for their planktonic foraminiferal populations and the oxygen- and carbon-isotope records of those populations. Comparison of benthic (Miller et al., this vol.) and planktonic foraminiferal oxygen-isotope curves shows that (1) the benthic record becomes somewhat more positive $(0.3 \%$ ) in the uppermost Eocene, whereas the planktonic record remains stable, and (2) both benthic and planktonic records increase by about $1 \% 0$ in the lowermost Oligocene. Planktonic foraminiferal population diversity, as measured by the information index, is quite variable in the upper Eocene and lower Oligocene. In the uppermost Eocene, diversity increases in unison with the changing benthic oxygen-isotope record. In the lowermost Oligocene, the diversity drops dramatically, and samples are dominated by only a few species. Farther upsection, sample diversity increases markedly. The oxygen-isotope record and population diversity for planktonic foraminifers seem to be best understood in terms of a model that incorporates both general ocean-water temperature and oceanic biological productivity. A preliminary interpretation suggests that the latest Eocene saw little change in surface ocean temperatures, but that there was an increase in productivity. In the earliest Oligocene there was a sudden drop in water temperature and productivity. After this, higher productivity conditions were reestablished, though temperatures may have remained cool.
\end{abstract}

\section{INTRODUCTION}

The purpose of this chapter is to present a preliminary examination of the planktonic foraminiferal populations spanning the Eocene/Oligocene boundary in Hole 549A. This hole is located southwest of Ireland in the northeastern Atlantic Ocean at $2533 \mathrm{~m}$ water depth. The Eocene/Oligocene boundary fauna are well preserved, and offer us the opportunity to study the changes in population structure that occurred in the northeastern Atlantic during a time of important oceanic readjustment. Relative abundance data for species are used to calculate diversity indices for late Eocene and early Oligocene populations, and a preliminary paleoceanic interpretation of these data is attempted. Stable-isotope values for the planktonic species Catapsydrax unicavus Bolli are used to help constrain the interpretation, particularly with respect to seawater temperature changes.

\section{METHODS}

Eight samples were selected from the upper Eocene and lower Oligocene, so as to match some of the samples used in the detailed benthic foraminiferal study of Miller et al. (this vol.). These samples (stiff calcareous ooze) were disaggregated by drying at less than $60^{\circ} \mathrm{C}$ and then soaking in distilled water. The material was then sieved at 149 $\mu \mathrm{m}$, and the residue was cleaned by a repetition of the drying procedure. This process is the same as is generally used for quantitative foraminiferal studies of Recent sediments. Samples were then split to a counting population of 200 to 600 individuals. Species identification follows the general scheme outlined in Stainforth et al. (1975), but some modification has been incorporated. A detailed description of species encountered is given in the discussion following. During the counting process a collection of SEM photographs of the planktonic foraminifers was made to substantiate identifications and to study the degree of test recrystallization for the stable-isotope analyses. A sub-

\footnotetext{
${ }^{1}$ Graciansky, P. C. de, Poag, C. W., et al., Init. Repts. DSDP, 80: Washington (U.S Govt, Printing Office).

Address: Dept. of Geology, Northern Illinois Univ., DeKalb, IL 60115.
}

set of these photographs, representing the most common species, is given in Plates 1 through 4 . Since the ecology of late Eocene to early Oligocene planktonic foraminifers is poorly known, the species-counting results are reported as a diversity index: $H(S)=-\Sigma P i \log P i$, where $P i$ is equal to the proportion of the $i$ th species. This was calculated using species more abundant than $1 \%$ of the sample. The less frequent species would make little contribution to $H(S)$, and their proportion could not be accurately determined without counting a very large number of individuals. The information index $H(S)$ offers us a general paleoenvironmental estimator, as discussed in Murray (1973). The equitability index, $E=H / H_{\max }$ (Dodd and Stanton, 1981), was also calculated to illustrate the degree of dominance in the foraminiferal populations. For this index, values range from 0 to 1 , with dominance increasing as the values become smaller.

The most persistent species in the samples, with abundances sufficient for isotopic analysis, was Catapsydrax unicavus-suteri Bolli. This form may encompass two species (see discussion in Stainforth et al., 1975). Scanning-electron micrographs (Plate 1) shows that the $C$. unicavus-suteri tests have not been significantly recrystallized. The foraminifers in the upper Eocene to lower Oligocene section of Hole $549 \mathrm{~A}$ are very well preserved (personal observation; Snyder and Waters, this vol.), and a number of species seem to have retained their original texture. It should be noted, however, that many of the smaller and more delicate forms show significant recrystallization. This is clear in the case of Globigerina cf. munda, shown in Plate 4, and Globigerina ciperoensis-angustiumbilicata (Plate 3).

For the isotopic analysis, about 100 individuals of $C$. unicavus-suteri per sample were repeatedly cleaned with ultrasound until the specimens were observed to be free of clinging sediment. Because the sediment samples were very clean carbonate oozes of considerable age (free of organic carbon), and because of the small size of the final available sample, the material was not cooked at $400^{\circ} \mathrm{C}$ in vacuo, as is done sometimes by other investigators (e.g., Shackleton and Kennett, 1975; Miller et al., this vol.). Sample loss in the handling required for the cooking would probably have resulted in samples too small for analysis. According to van Donk (1977), cooking foraminifers leads to a $0.2 \%$ decrease in oxygen-isotope values, so the results reported here may be considered about $0.2 \%$ heavier than would be expected for records based on cooked material.

The samples were reacted with orthophosphoric acid at $50^{\circ} \mathrm{C}$ and then analyzed using a Varian Mat 250 mass spectrometer. Analytical precision of standards in our laboratory is within $0.1 \% 0$ for $\delta^{18} \mathrm{O}$ and within $0.05 \%$ for $\delta^{13} \mathrm{C}$. All analyses were run against the standard NBS-20. The results were corrected for temperature of reaction and then referred to the PDB standard using the equation of Garlick (1978). 


\section{DESCRIPTION OF THE FORAMINIFERAL POPULATIONS}

The relative abundances of the planktonic foraminiferal species in the samples studied here are presented in Table 1 . The table contains only species present in amounts greater than $1 \%$. The most important species in each sample are described in the subsequent discussion, and are also illustrated in the scanning-electron micrographs of Plates 1 through 4 . The descriptions given here are prepared as notes for each sample studied, giving particular emphasis to species that are equivocally identified or which cannot be definitively named at this time.

\section{Sample 549A-35-1, $42 \mathrm{~cm}$}

Globigerina eocaena Gümbel: Plate 2, Figures 1-4. Included in this category is $G$. galavisi of some authors (e.g., Plate 2, Fig. 2, compared with Berggren and Amdurer, 1973, pl. 26, figs. 1 and 2), which is not abundant in the sample. Plate 2, Figure 4 illustrates a form of $G$. eocaena which develops an apertural flap or kummerform chamber; this form is common in the sample.

Globigerina sp.: Plate 2, Figures 5 and 6 . This taxon is similar to $G$. eoceana, but shows a slow rate of increase in chamber size, and the final and penultimate chambers are nearly the same size. Also, the taxon has a well-developed lip along a low umbilical aperture. The

Table 1. Planktonic foraminiferal species abundance across the Eocene/Oligocene boundary, Hole 549A. (Species less than $1 \%$ not included.)

\begin{tabular}{|c|c|c|c|c|c|c|c|c|}
\hline \multirow[b]{2}{*}{ Species } & \multicolumn{8}{|c|}{ Sample (position in $\mathrm{cm}$ ) } \\
\hline & $35-1,42$ & $33-1,141$ & $24-2,123$ & $17-1,80$ & $15-2,80$ & $12-1,60$ & $11-1,30$ & $10-6,40$ \\
\hline Globigerina eocaena & 20.8 & 3.0 & 10.0 & 10.0 & $1.7 / 1.7^{\mathrm{a}}$ & 5.4 & 4.2 & 12.9 \\
\hline Globigerina sp. & 16.1 & & 2.4 & & & & & \\
\hline Catapsydrax unicavus & 12.0 & 1.1 & 2.4 & 5.0 & 1.0 & & 3.1 & 3.3 \\
\hline Catapsydrax suteri & 11.1 & 4.2 & 8.9 & 3.6 & 1.7 & 9.9 & 2.9 & 5.1 \\
\hline Globigerina venezuelana & 10.1 & 3.0 & 6.2 & 5.0 & 1.0 & 5.9 & 6.8 & 1.9 \\
\hline Globigerinatheka index & 8.3 & $\begin{array}{c}4.9 \\
10.7^{b}\end{array}$ & $\begin{array}{l}1.4 \\
3.0^{\mathrm{b}}\end{array}$ & & & & & \\
\hline $\begin{array}{l}\text { Globigerina eocaena-venezuelana } \\
\text { (intermediate) }\end{array}$ & 4.1 & 1.9 & 1.1 & 1.4 & 1.4 & 5.0 & & \\
\hline Globigerina linaperta & 3.2 & 43.0 & 3.8 & 4.6 & 1.4 & 1.7 & 5.0 & 3.1 \\
\hline Globorotalia cerroazulensis & 2.8 & 1.1 & & & & & & \\
\hline Globigerina pseudobulloides & 2.3 & & 4.0 & & & & & \\
\hline Globorotaloides sp. & 2.3 & 1.5 & 11.9 & & & 2.4 & & \\
\hline $\begin{array}{c}\text { Globigerina ciperoensis-angusti- } \\
\text { umbilicata (intermediate) }\end{array}$ & & 6.5 & 8.1 & 2.7 & 3.1 & 3.1 & 6.2 & 5.2 \\
\hline Globigerina angustiumbilicata & & & 1.6 & 3.2 & 1.4 & 1.9 & & \\
\hline Catapsydrax dissimilis & & 5.7 & & & & & 5.8 & 2.4 \\
\hline Globorotalia sp. & & 1.5 & & & & & & \\
\hline Globigerina angiporoides & & 2.3 & & 1.8 & & & 1.8 & \\
\hline Globorotalia sp. (hagni) & & & 6.7 & 2.7 & & & & \\
\hline Globigerina praebulloides & & & 2.2 & 4.9 & & & & 3.0 \\
\hline Globorotalia increbescens & & & 1.4 & 8.6 & & & & \\
\hline Globorotalia sp. 2 & & & 3.2 & 2.3 & 14.6 & 9.2 & 11.0 & 7.4 \\
\hline $\begin{array}{l}\text { Coarse-textured Globigerina } \\
\text { eocaena }\end{array}$ & & & 3.8 & & & & & 3.4 \\
\hline Globigerina sp. & & & 2.4 & & & & & \\
\hline Globigerina cf. eocaena & & & & 10.4 & & & & \\
\hline Globigerina oachitensis & & & & 4.0 & & 2.8 & 4.6 & 4.6 \\
\hline Globigerina tapuriensis & & & & 5.0 & 47.3 & 13.0 & & \\
\hline $\begin{array}{l}\text { Globigerina tapuriensis-eocaena } \\
\text { (intermediate) }\end{array}$ & & & & 4.0 & & & & \\
\hline Globigerina ampliapertura & & & & 3.6 & 7.5 & 12.1 & & 4.2 \\
\hline Globigerina opima nana & & & & 1.4 & & 2.4 & & \\
\hline Globigerina sp. & & & & 1.4 & & & & \\
\hline Globigerina gortanii & & & & 3.2 & & & 4.4 & \\
\hline $\begin{array}{l}\text { Globigerina eocaena-praebul- } \\
\text { loides (intermediate) }\end{array}$ & & & & 4.0 & & & & \\
\hline Globigerina tripartita & & & & & 5.1 & 2.6 & & \\
\hline Globigerina euaperta & & & & & 3.1 & & 10.2 & 1.3 \\
\hline Globigerina munda & & & & & & 1.4 & 14.8 & 16.0 \\
\hline Globigerina cf. eocaena 2 & & & & & & 4.5 & 3.8 & \\
\hline$\Sigma 4$ Globigerina spp. ${ }^{\mathrm{c}}$ & & & & & & 6.9 & & \\
\hline Globigerina corpulenta & & & & & & & 2.0 & \\
\hline Globigerina obesa & & & & & & & 1.5 & 2.2 \\
\hline Globorotalia postcretacea & & & & & & & 1.5 & \\
\hline Globigerina opima opima & & & & & & & 1.3 & 1.5 \\
\hline Globigerina officinalis & & & & & & & 1.1 & 1.6 \\
\hline Globigerina sellii & & & & & & & & 1.3 \\
\hline Globigerina cf. gortanii & & & & & & & & 1.2 \\
\hline Globigerina $\mathrm{cf}$ ciperoensis & & & & & & & & 1.0 \\
\hline$\Sigma 6$ Globigerina spp. ${ }^{\mathrm{c}}$ & & & & & & & & 9.0 \\
\hline
\end{tabular}

${ }^{\mathrm{a}}$ Kummerform.

$\mathrm{b}$ One aperture only.

$\mathrm{c}_{\Sigma}=$ sum of percents of unnamed Globigerina species. 
taxon is similar to the illustration of Globigerina inaequispira Subbotina in Loeblich and Tappan (1957, pl. 52, fig. 2), but does not match their description of a form with rapidly increasing chamber size.

Catapsydrax suteri (Bolli) and C. unicavus Bolli, Loeblich, and Tappan: Plate 1. These taxa are separated on the basis of test compression and spire height. C. suteri includes forms with more inflated chambers and a somewhat raised spire (compare Stainforth et al., 1975, figs. 146 and 149).

Globigerinatheka index (Finlay): Plate 2, Figures 7 and 8. Many individuals of this species lack secondary apertures (Plate 2, Fig. 8). However, the morphology of these forms was identical to typical specimens of $G$. index conforming to the illustrations of Stainforth et al. (1975, fig. 56).

\section{Sample 549A-33-1, $141 \mathrm{~cm}$}

Globigerina linaperta Finlay: Plate 2, Figures 9 and 12. The form illustrated in Plate 2 has an aperture lower and somewhat more marginal than that of the species illustrated by Stainforth et al. (1975). The G. linaperta of Sample 549A-33-1, $141 \mathrm{~cm}$ is more similar to forms illustrated in Ellis et al. (1969, figures 32 [Austria] and 35 [Japan]), as well as in Bolli (1957a, Trinidad). This form of G. linaperta is dissimilar to the illustrations of Blow and Banner (1962), which show the species to have a higher arched umbilical aperture.

Globigerina ciperoensis angustiumbilicata Bolli: Plate 3 , Figures 2 and 3 . This taxon was described by Bolli (1957b) on the basis of Oligocene material from Trinidad. It is found in Oligocene sediments of Hole 549A (see the following), and the upper Eocene form found in Sample 549A-33-1, $141 \mathrm{~cm}$ appears to be identical to its Oligocene counterpart.

\section{Sample 549A-24-2, $123 \mathrm{~cm}$}

Globorotaloides sp.: Plate 2, Figures 10 and 11. This taxon resembles the Subbotina varianta (Subbotina) illustrated by Tjalsma (1977, pl. 3, figs. 1-3) using material from the South Atlantic. However, $S$, varianta was originally described using specimens from Paleocene material, and Tjalsma's specimens come from lower Eocene sediments. The taxon also resembles the Globorotaloides sp. of McKeel and Lipps (1975, pl. 3, fig. 2) described using specimens from middle Eocene sediments of the Oregon coast range.

Globorotalia sp.: Plate 3, Figures 1 and 4. This taxon closely resembles Globigerina hagni Gohrbrandt, as illustrated by Toumarkine (1975, pl. 1, figs. 7 and 8). The illustrated form has a spire composed of a planispiral arrangement of chambers gradually increasing in size until the last whorl, which is offset from the rest of the test and composed of rounded chambers rapidly increasing in size. The aperture is umbilical with a distinct lip.

\section{Sample 549A-17-1, $80 \mathrm{~cm}$}

G. cf. eocaena: The final and penultimate chambers in this form are nearly the same size, the aperture is arched interio-marginal, and no apertural tooth is present as in other G. eocaena. This form appears to bear a relationship to G. eocaena that is similar to the relationship of $G$. falconensis to $G$. bulloides in modern sediments.

Globorotalia increbescens (Bandy): Plate 3, Fig. 5. The form illustrated resembles the photographs in both Stainforth et al. (1975, fig. 123) and Stainforth and Lamb (1981, pl. 3, fig. 4).

Globigerina ouachitensis Howe and Wallace: The form found in this sample is identical to that illustrated in Stainforth and Lamb (1981, pl. 6, fig. 2).

Globigerina tapuriensis Banner and Blow: Plate 3, Figures 10 and 11 . This form is very similar to that illustrated by Jenkins and Orr (1972, pl. 11, figs. 7-9). Also present are $G$. eocaena-tapueriensis intergrade forms with an apertural flap or kummerform chambers; this makes species distinction difficult.

\section{Sample 549A-15-2, $80 \mathrm{~cm}$}

Globorotalia sp. 2: Plate 3, Fig. 12; Plate 4, Figures $1-3$. This taxon superficially resembles Globorotalia opima (Plate 4, Figs. 5 and 6), but does not have the typical depressed spire (see Stainforth and Lamb, 1981, pl. 4 , figs. 1 and 2); nor does it have G. opima's interiomarginal aperture. Rather, the aperture for Globorotalia sp. 2 is entirely umbilical. This taxon also superficially resembles Globigerina angiporoides (Plate 4, Fig. 4), but does not possess its coarser texture or its cross-like mode of chamber addition (chambers aligned at $45^{\circ}$ to one another along a whorl; see Stainforth et al., 1975, fig. 103). Rather, the coiling in Globorotalia sp. 2 is of the standard "Globigerina" type. The specimens investigated here have a well-preserved "pitted" texture (Plate 4, Fig. 2) indicative of the genus Globorotalia, as the term is used with Paleogene taxa.

Globigerina ampliapertura Bolli: Plate 3, Figures 7 and 8 . The form illustrated here is similar to that of Jenkins and Orr (1972, pl. 2, figs. 7-9) in having a high, nearly circular aperture with a lip. It is different from those illustrated in Stainforth et al. (1975, fig. 102), Blow and Banner (1962, pl. 11), Stainforth and Lamb (1981, pl. 3), and Bizon et al. (1972, p. 143), all of which have a broader, lower aperture. Note that the $G$. ampliapertura form in the upper Eocene of Hole 549A (Sample 549A-24-2, $123 \mathrm{~cm}$, Plate 3, Figs. 6 and 9) differs from its Oligocene counterpart in having a broader, lower aperture and a spire which is partly embraced by the final whorl of chambers. The spiral arrangement is different in the Oligocene form, as can be seen by comparing Figures 8 and 9 of Plate 3. This morphologic variation may represent a trend which could have biostratigraphic value.

\section{Sample 549A-11-1, $30 \mathrm{~cm}$}

Globorotalia munda Jenkins: Plate 4, Figures 7-9, 13. This form is similar to that of Poore $(1979$, pl. 20 , figs. 8-10, 11-13) and Tjalsma (1977, pl. 4, figs. 7-11). As can be seen from Plate 4, Figures 9 and 13, the surface texture of this species has been extensively modified by recrystallization.

Globigerina euaperta Jenkins: Plate 4, Figure 12. The form illustrated is similar to those of Jenkins and Orr (1972, pl. 9). For this sample, forms have a lower 
aperture than that originally described by Jenkins (1960).

G. linaperta: Plate 4, Figures 10 and 11. The form here is similar to those illustrated by Blow and Banner (1962, pl. 11, figs. $\mathrm{H}$ and $\mathrm{M}$ ).

\section{STABLE-ISOTOPE RESULTS FOR THE PLANKTONIC FORAMINIFERS}

Isotopic results for the planktonic species Catapsydrax unicavus-suteri are presented in Table 2 and Figure 1. On Figure 1 the results are compared with the benthic foraminiferal analyses of Miller et al. (this vol.). The planktonic oxygen-isotope curve appears fairly stable, with values between 0.1 and $0.4 \%$ PDB for the latest Eocene. Following this there is an abrupt increase in val-

Table 2. Oxygen and carbon isotopic analyses $\left(\%_{0}\right)$ and values of information index, $H(S)$, and equitability index, $E$, for the planktonic foraminiferal species Catapsydrax unicavus-suteri (Hole 549A).

\begin{tabular}{lcccccc}
\hline $\begin{array}{c}\text { Sample } \\
\text { (position in cm) }\end{array}$ & $\begin{array}{c}\text { Sub-bottom } \\
\text { depth (m) }\end{array}$ & Zone & $H(S)$ & $E$ & $\delta^{18} \mathrm{O}$ & $\delta^{13} \mathrm{C}$ \\
\hline $10-6,40$ & 91.9 & P20 & 1.20 & 0.83 & & \\
$11-1,30$ & 93.5 & P20 & 1.19 & 0.89 & & \\
$12-1,60$ & 103.6 & P19-P20 & 1.15 & 0.86 & 1.18 & 1.02 \\
$15-2,80$ & 118.3 & P18 & 0.66 & 0.63 & 0.90 & 1.34 \\
$17-1,80$ & 123.3 & P18 & 1.26 & 0.97 & 0.38 & 1.25 \\
$24-2,123$ & 134.7 & P17 & 1.16 & 0.85 & 0.17 & 0.81 \\
$33-1,141$ & 151.9 & P16 & 0.85 & 0.71 & 0.14 & 1.21 \\
$35-1,42$ & 160.9 & P15 & 0.90 & 0.86 & & \\
\hline
\end{tabular}

Note: Isotope values referred to PDB standard. ues to about $1.2 \%$ PDB for the early Oligocene. This represents an enrichment of about $1 \%$, which is similar to late Eocene to early Oligocene enrichments reported for the high-latitude Pacific by Shackleton and Kennett (1975) and Keigwin (1980) for planktonic foraminifers. In Hole 549A (Fig. 1), the planktonic enrichment matches a similar event for the benthic foraminifers, which shows an enrichment of about $0.8 \% 0$ in the earliest Oligocene. Hence, the benthic and planktonic records of the northeastern Atlantic for the earliest Oligocene are very similar to the record reported for the Campbell Plateau in the high-latitude South Pacific.

In specimens deposited in the late Eocene (Zones P16-early P17) of Hole 549A, there is a divergence between the oxygen isotopic records of the benthic and planktonic foraminifers. Over this span the benthic record becomes about 0.5 heavier, and the planktonic record remains fairly constant. This phenomenon has also been reported in the South Atlantic at DSDP Site 522 (present lat.: $26^{\circ} \mathrm{S}$; Poore and Matthews, in press); it is not seen in any of the Pacific records mentioned earlier.

\section{FORAMINIFERAL POPULATION DIVERSITY AND EQUITABILITY}

The diversity and equitability indices of the samples studied here are listed in Table 2 , and the diversity index, $H(S)$, is plotted on Figure 1. Also shown on Figure 1 are species-abundance histograms of the foraminiferal populations. These histograms show the species percentages plotted sequentially from most to least abun-
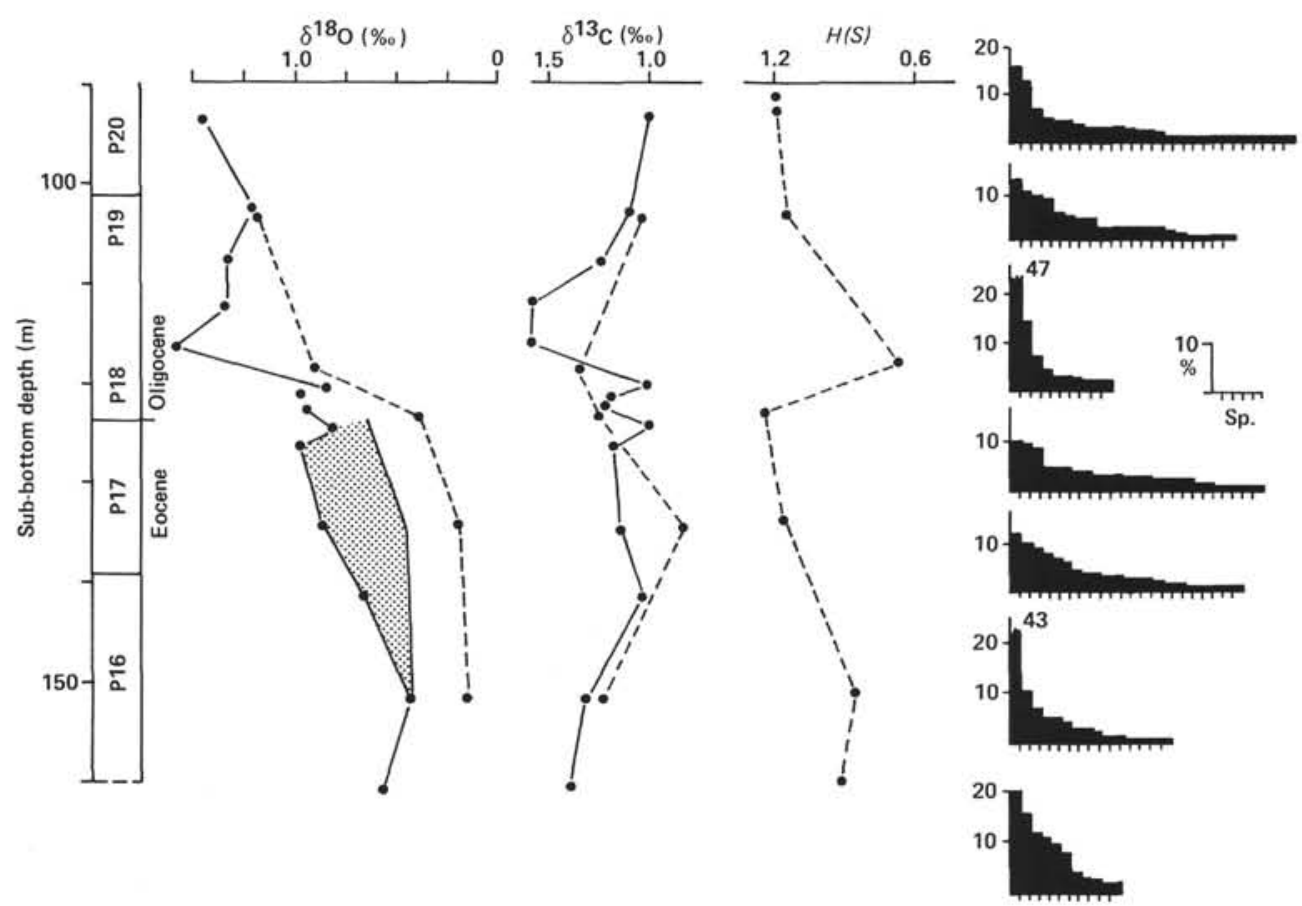

Figure 1. Isotopic records $(\% 0)$ and planktonic foraminiferal population diversity records. Zonation according to Snyder and Waters (this vol.). Solid lines = benthic foraminiferal values, dashed lines = planktonic values. Stippled area represents deviation of the benthic record from the planktonic record. $H(S)=$ information index. Histograms corresponding to the various samples show species abundances arranged in decreasing order. The histogram for the youngest sample is omitted since it is nearly identical to the histogram of the second-youngest sample. Numbers by histograms indicate percentages of the most abundant species. 
dant, and illustrate the degree of species dominance in a sample.

In Zones P16 and P17, over the interval in which the benthic foraminiferal oxygen-isotope record diverges from the planktonic record, the species diversity of the planktonic foraminifers increases from moderate values to quite high values near the Eocene/Oligocene boundary. The planktonic populations in the upper Eocene show a regular increase in number of species comprising more than $1 \%$ of the sample and a decrease in species dominance. Thus, the planktonic populations in Zone P16 are dominated by a small number of species, whereas among the populations of Zone P17, individuals are more evenly distributed among all the species.

In the lowermost Oligocene, diversity is low and dominance is high. The sample from Zone P18 is dominated by only two species, and contains a small number of species present in quantities greater than $1 \%$. Through Zones P19 and P20, the foraminiferal population structure returns to greater diversity and lower dominance.

\section{Interpreting Foraminiferal Diversity}

Planktonic foraminiferal diversity reflects water temperature and surface ocean circulation systems (Stehli, 1965; Balsam and Flessa, 1978). The trend of high diversity in warm water and low diversity in cold water has been noted in many marine animals. Beyond this, however, planktonic foraminiferal diversity can also be associated with oceanic biological productivity. This has been demonstrated for the North Atlantic by Ruddiman (1969), who examined the "percent of most abundant species" in Recent sediments. The relationship between diversity and productivity can be seen in Figure 2, which shows $H(S)$ calculated for Kipp's (1976) extensive data set for North Atlantic surface-sediments assemblages.

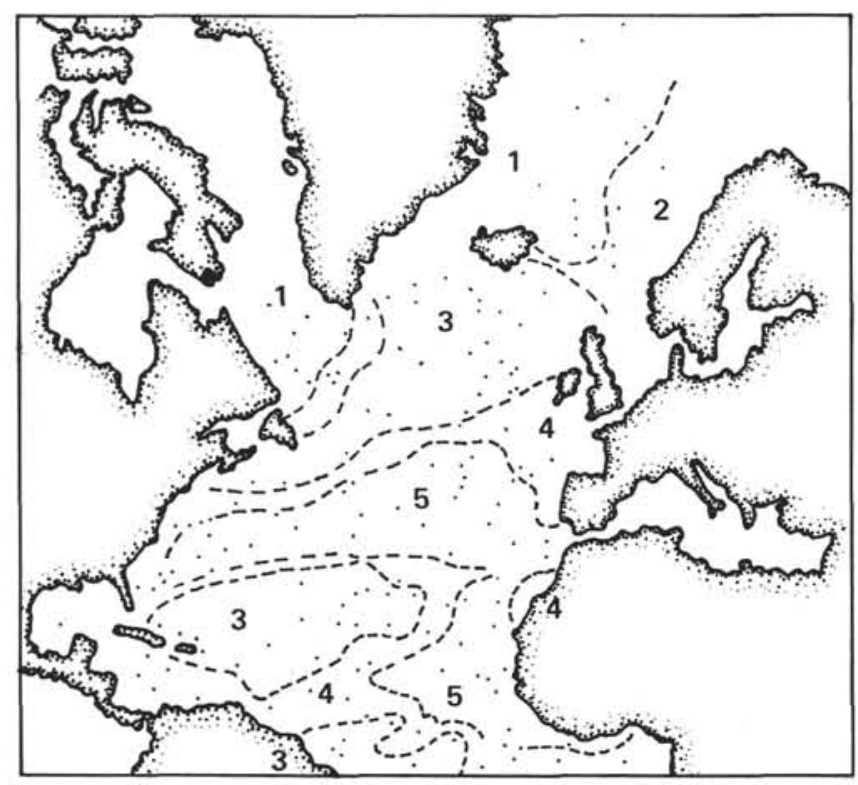

Figure 2. Information-index diversity for the North Atlantic surfacesediment populations of Kipp (1976). Dots show core locations. 1: values less than $0.43 ; 2$ : between 0.43 and $0.65 ; 3$ : between 0.65 and $0.87 ; 4$ : between 0.87 and $1.0 ; 5$ : greater than 1.0 .
There is a low in foraminiferal diversity in the southern Sargasso Sea, where productivity is very low and oceanic conditions do not vary greatly over the average year (see U.S. Naval Oceanographic Atlas, 1967). From Figure 2 it can be seen that foraminiferal diversity is highest in warm (not necessarily tropical), productive ocean waters, and that diversity decreases both as productivity decreases and as average annual ocean water temperature decreases, as in the temperate and subarctic regions of the North Atlantic.

Since diversity reflects both temperature and productivity, an interpretation of the information indices of the samples studied here requires that we constrain one of these variables. The planktonic oxygen-isotope record will be used to estimate general temperature changes, and this will allow us to draw some tentative inferences concerning productivity variations across the Eocene/ Oligocene boundary in the northeastern Atlantic.

Another influence that must be considered in examining the diversity values for the planktonic populations is the impact of extinctions and changes in the total number of planktonic foraminiferal species present in the world ocean through Eocene and Oligocene time (Lipps, 1970; Tappan and Loeblich, 1973). Reductions in the total number of taxa, particularly at the Eocene/Oligocene boundary, would affect the values calculated for the information index. This index is a function not only of the distribution of individuals among the species (dominance), but also of the total number of species present in a sample. The distribution of individuals among species is reflected in the population dominance, as seen in the equitability values of Table 2 and the histograms of Figure 1. Periods of extinction will affect the number of species present, but they need not affect the species dominance of populations. We may have a low species number but also low dominance (individuals evenly divided among species present). Hence, an extinction event will cause the information-index value to decrease, but it need not affect the observed or calculated species dominance. In this study there is a decrease in the number of species present across the Eocene/Oligocene boundary, but, more important for paleoceanic interpretation, there is also a large increase in dominance. The shifts recorded in both diversity and dominance will be used here for interpretative purposes.

\section{A Tentative Paleoceanic Interpretation for the Eocene/Oligocene Boundary of Hole 549A}

Within Zones P16 and P17 (Fig. 1), the benthic oxygen isotopic record diverges somewhat from the planktonic record. Coincident with this, the species diversity of the planktonic foraminifers increases from moderate values in the lower part of Zone P16 to quite high values near the Eocene/Oligocene boundary. An examination of the species-dominance histograms shows a pattern of decreasing dominance through the late Eocene. Over this period the presence of moderate quantities of warmer-water species (e.g., Globigerinatheka index) suggests at least temperate oceanic conditions. Also, the relative stability of the planktonic isotopic results over Zones P16 and P17 (change of less than $0.25 \%$ ) suggests that 
upper-ocean water temperature did not change a great deal in this interval. So it would seem likely that the increase in foraminiferal diversity toward the end of the late Eocene was associated with a shift in oceanic conditions favoring higher productivity, rather than with a temperature change. This shift was coincident with changes developing in the bottom waters of the region, as described by Miller et al. (this vol.) and reflected in the benthic isotope record presented in Figure 1. It should be noted that the assemblages examined here for the late Eocene are all different, indicating that a complex series of oceanographic changes and taxic evolutionary/extinction events must have been occurring.

Within Zone P18 of the lower Oligocene, both benthic and planktonic foraminiferal oxygen-isotope records increase considerably in value. For the planktonic species there is an increase of about $0.8 \%$. Coincident with this there is a considerable decrease in the planktonic population deversity. The lower Oligocene population is essentially composed of three species, and is dominated by one species. By analogy with the modern North Atlantic (Fig. 2), such a low diversity would be associated with polar water temperatures. The isotopic shift for the planktonic species of the early Oligocene would probably not represent more than a 3 or $4^{\circ} \mathrm{C}$ decrease in temperature (from temperature scale of Shackleton and Kennett, 1975), so it would seem unlikely that the associated diversity drop could be entirely explained by the temperature change. However, a decrease in oceanic productivity and a drop in temperature would produce low foraminiferal diversity and high species dominance. The idea of a period of low productivity in the northeastern Atlantic during the early Oligocene appears substantiated by the rest of the early Oligocene record from Zones P19 and P20. Within Zone P19 the planktonic oxygen-isotope values remain high while the population deversity increases markedly to values close to those recorded for the late Eocene. It seems likely that the assemblages of Zones P19 and P20 represent quite productive waters. It should be noted that there is a progressive change in common species from Zones P18 to P20, indicating changing oceanic conditions and/or evolving foraminiferal taxa.

\section{CONCLUSIONS}

Conclusions must be tentative, since only a small number of samples were examined. However, the oxygen-isotope record and the population diversity for planktonic foraminifers from the late Eocene to early Oligocene of the northeastern Atlantic seem best interpreted in terms of a model that incorporates both general oceanwater temperature and oceanic productivity:

1. In the latest Eocene, surface water temperatures did not change very much, but surface ocean conditions changed to favor higher productivity. Conditions before this were probably only moderately productive. The change in surface conditions was coincident with changes occurring in the deep North Atlantic.

2. In the early Oligocene, there was a sudden drop in surface water temperature and productivity. This oc- curred during the worldwide early Oligocene oceanic event.

3. After this, water temperatures in vicinity of Hole 549A may not have increased very much, but population diversity did, suggesting a restructuring of oceanic conditions favoring an increase in productivity.

\section{ACKNOWLEDGMENTS}

Thanks are due Professor E. C. Perry, who helped construct the preparation line that allowed me to measure the stable isotopes of small samples of foraminifers. Rick Socki helped maintain equipment in our mass-spectrometer laboratory. Reviews by Molly Murphy, Professor J. Kennett, and reviewers selected by W. Poag helped considerably improve this manuscript.

\section{REFERENCES}

Balsam, W., and Flessa, K., 1978. Patterns of planktonic foraminiferal abundance in surface sediments of the western North Atlantic. Mar. Micropaleontol, 3:279-294.

Berggren, W., and Amdurer, M., 1973. Late Paleogene (Oligocene) and Neogene planktonic foraminiferal biostratigraphy of the Atlantic Ocean. Riv. Ital. Paleont., 79(3):337-392.

Bizon, G., Bizon, J., Aubert, J., and Oertli, H., 1972. Atlas des Principaux Foraminiferes Planctoniques du Bassin Mediterranean: Paris (Editions Technip).

Blow, W., and Banner, F., 1962. The mid-Tertiary (upper Eocene to Aquitanian) Globigerinaceae. In Eames, F., Banner, F., Blow, W., and Clarke, W. (Eds.), Fundamentals of Mid-Tertiary Stratigraphical Correlation: Cambridge (Cambridge University Press).

Bolli, H., 1957a. Planktonic Foraminifera from the Oligocene-Miocene Cipero and Lengua formations of Trinidad, B. W. I. U.S. Natl. Mus. Bull., 215:97-154.

1957b. Planktonic Foraminifera from the Eocene Navet and San Fernando formations of Trinidad, B. W. I. U.S. Natl. Mus. Bull., 215:155-172.

Dodd, J., and Stanton, R., 1981. Paleoecology, Concepts and Applications: New York (John Wiley and Sons).

Ellis, B., Messina, A., Charmatz, R., and Ronai, L., 1969. Catalogue of Index Smaller Foraminifers, (Vol. 2): New York (Amer. Mus. Natl. Hist.).

Garlick, G., 1978. The stable isotopes of oxygen. In Wedepohl, K., et al., (Eds.), Handbook of Geochemistry: New York (SpringerVerlag), pp. 8-B-1 to 8-B-27.

Jenkins, G., 1960. Planktonic Foraminifera from the Lakes Entrance oil shaft, Victoria, Australia. Micropaleontology, 6(4): 345-371.

Jenkins, G., and Orr, W., 1972. Planktonic foraminiferal biostratigraphy of the eastern equatorial Pacific, Leg 9. In Hays, J., et al., Init. Repts. DSDP, 9: Washington (U.S. Govt. Printing Office), pp. 1059-1193.

Keigwin, L., 1980. Paleoceanographic change in the Pacific at the Eocene-Oligocene boundary. Nature, 287:722-725.

Kipp, N., 1976. New transfer function for estimating past sea-surface conditions from sea-bed distribution of planktonic foraminiferal assemblages in the North Atlantic. In Cline, R., and Hays, J. (Eds.), Investigation of Late Quaternary Paleoceanography and Paleoclimatology. Mem. Geol. Soc. Am., 145:3-42.

Lipps, J., 1970. Plankton evolution. Evolution, 24(1):1-22.

Loeblich, A., and Tappan, H., 1957. Planktonic Foraminifera of Paleocene and early Eocene age from the Gulf and Atlantic Coastal plains. U.S. Natl. Mus. Bull., 215:173-198.

McKeel, D., and Lipps, J., 1975. Eocene and Oligocene planktonic Foraminifera from the central and southern Oregon coast range. $J$. Foram. Res., 5(4):249-269.

Murray, J., 1973. Distribution and Ecology of Living Benthic Foraminiferids: New York (Crane, Russak).

Poore, R., 1979. Oligocene through Quaternary planktonic foraminiferal biostratigraphy of the North Atlantic: DSDP Leg 49. In Luyendyk, B. P., Cann, J. R., et al., Init. Repts. DSDP, 49: Washington (U.S. Govt. Printing Office), 447-581.

Poore, R., and Matthews, R., in press. Late Eocene-Oligocene oxygen- and carbon-isotope record from South Atlantic Ocean, Deep 
Sea Drilling Project Site 522. In Hsü, K. J., LaBrecque, J. L., et al., Init. Repts. DSDP, 73: Washington (U.S. Govt. Printing Office), 725-736.

Ruddiman, W., 1969. Recent planktonic Foraminifera: Dominance and diversity in North Atlantic surface sediments. Science, 164: $1164-1167$.

Shackleton, N., and Kennett, J., 1975. Paleotemperature history of the Cenozoic and the initiation of Antarctic glaciation: Oxygen and carbon isotope analyses in DSDP Sites 277,279 and 281 . In Kennett, J. P., Houtz, R. E., et al., Init. Repts. DSDP, 29: Washington (U.S. Govt. Printing Office), 743-756.

Stainforth, R. M., Lamb, J. L., Luterbacher, H., Beard, H. J., and Jeffords, R. M., 1975. Cenozoic planktonic foraminiferal zonation and characteristics of index forms. Univ. Kan. Paleont. Contrib., Article 62.

Stainforth, R. M., and Lamb, J. L., 1981. An evaluation of planktonic foraminiferal zonation of the Oligocene. Univ. Kan. Paleont. Contrib., Paper 104.

Stehli, F., 1965. Paleontological technique for defining ancient ocean currents. Science, 148:943-946.
Tappan, H., and Loeblich, A., 1973. Evolution of the ocean plankton. Earth Sci. Rev., 9:207-240.

Tjalsma, R., 1977. Cenozoic Foraminifera from the South Atlantic, DSDP Leg 36. In Barker, P. F., and Dalziel, I. W. D., et al., Init. Repts. DSDP, 36: Washington (U.S. Govt. Printing Office), 493-518.

Toumarkíne, M., 1975. Middle and late Eocene planktonic Foraminifera from the northwestern Pacific, Leg 32 of the Deep Sea Drilling Project. In Larson, R. L., Moberly, R., et al., Init. Repts. DSDP, 32: Washington (U.S. Govt. Printing Office), 735-752.

U.S. Naval Oceanographic Atlas, 1967. Sec. 2: Physical Properties. Washington (U.S. Naval Oceanographic Office).

van Donk, J., 1977. O-18 as a tool for micropaleontologists. In Ramsay, A., (Ed.), Oceanic Micropaleontology (Vol. 2): London (Academic Press), pp. 1345-1370.

Date of Initial Receipt: March 7, 1983

Date of Acceptance: July 18, 1983
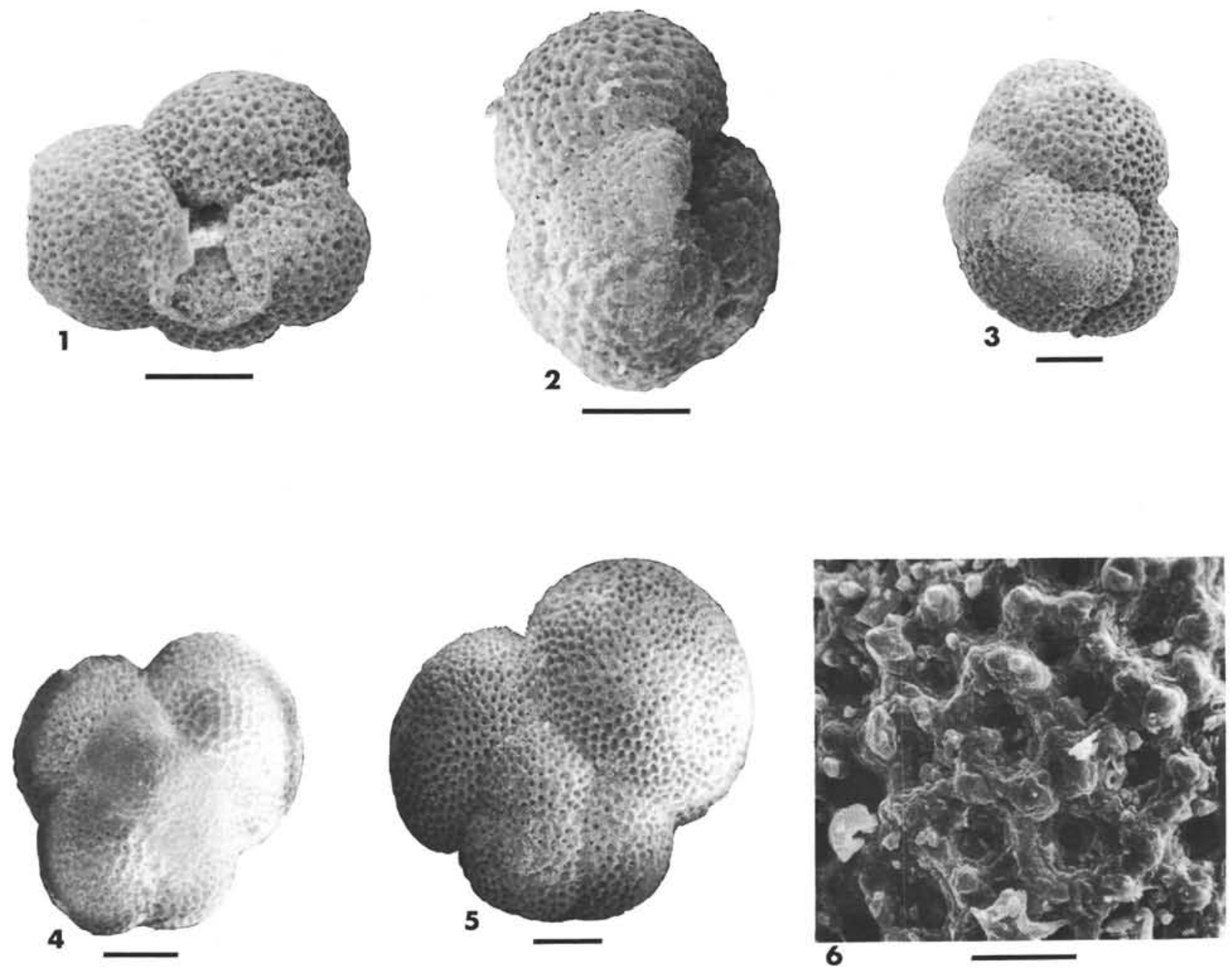

Plate 1. Catapsydrax species. (Scale bars $=100 \mu \mathrm{m}$, unless otherwise indicated.) 1. C. unicavus with bulla removed. 2-3. C. suteri. 4. Muchinflated C. suteri, umbilical view. 5. Spiral view of $G$. dissimilis showing difference from C. suteri. 6. Enlargement of $G$. unicavus texture, Scale bar $=20 \mu \mathrm{m}$. 

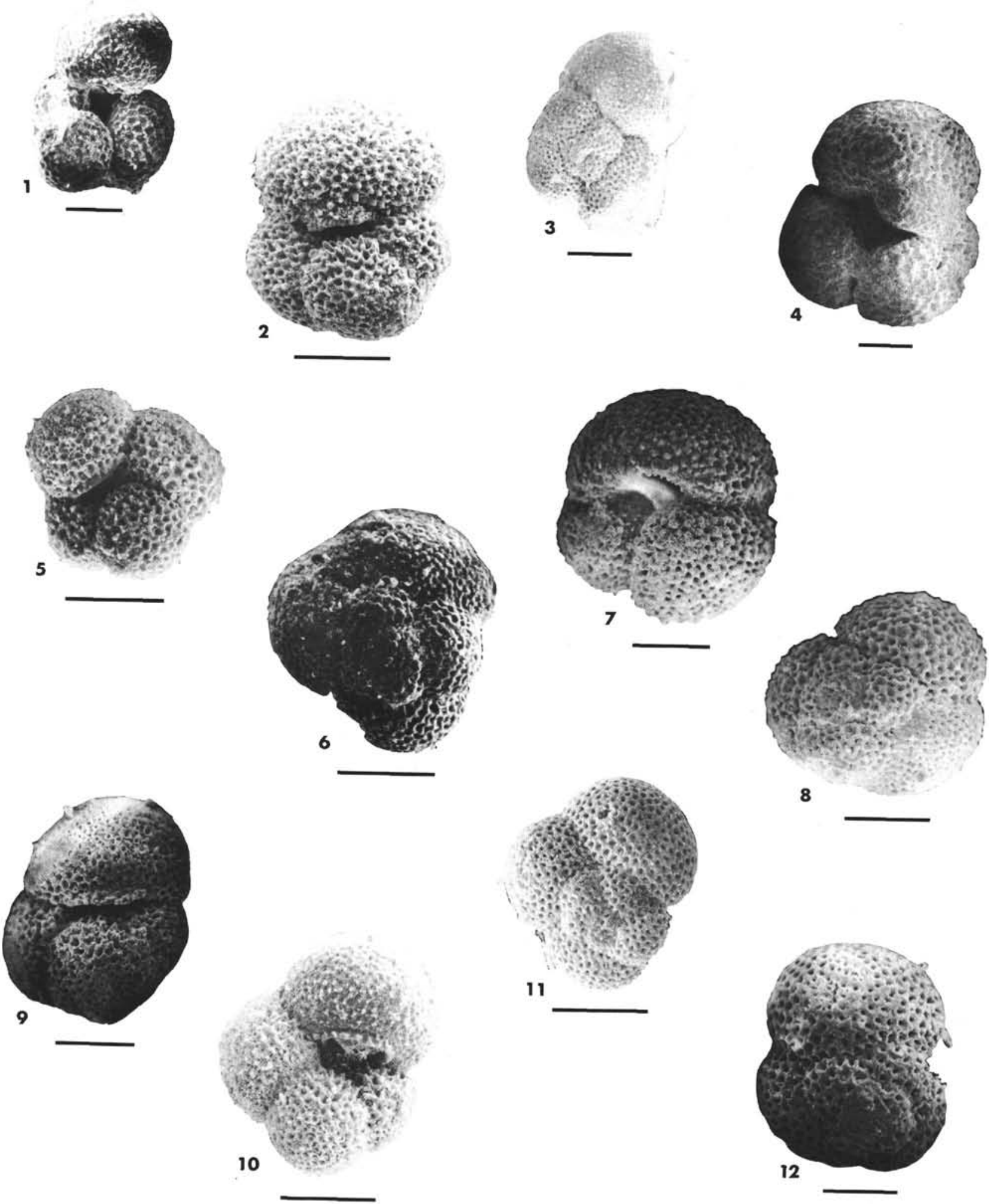

Plate 2. (All scale bars $=100 \mu \mathrm{m}$.) 1, 3. G. eocaena, Sample 549A-24-2, $123 \mathrm{~cm}$. 2. G. eocaena-galavisi, Sample 549A-24-2, 123 cm. 4. Kummerform G. eocaena, Sample 549A-10-6, $40 \mathrm{~cm}$. 5-6. Globigerina sp. Sample 549A-35-1, $42 \mathrm{~cm}$. 7-8. G. index, Sample 549A-33-1, 141 cm. 9, 12. G. linaperta, Sample 549A-33-1, $141 \mathrm{~cm}$. 10-11. Globorotaloides sp., Sample 549A-24-2, $123 \mathrm{~cm}$. 

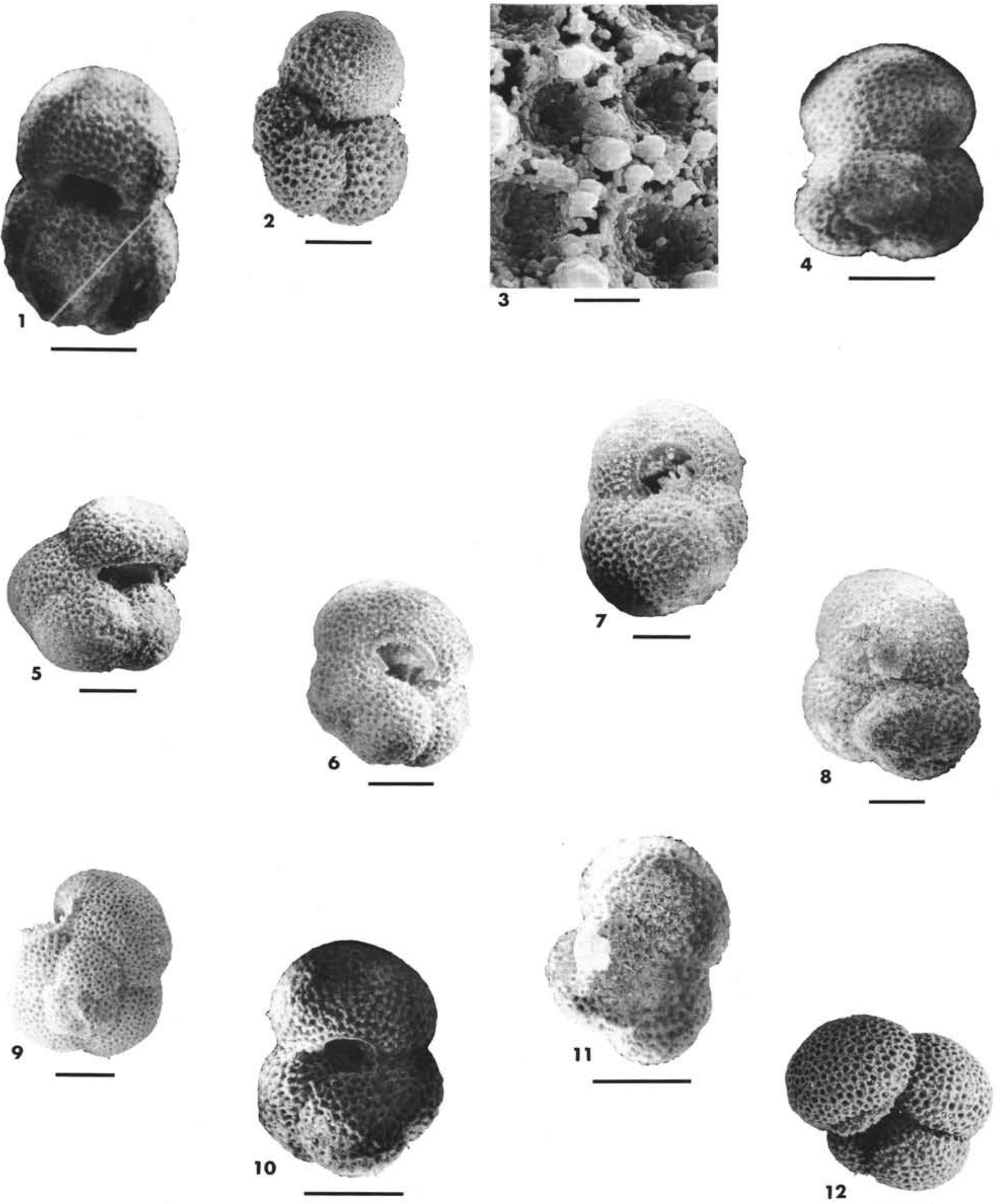

Plate 3. (Scale bars $=100 \mu \mathrm{m}$, unless otherwise indicated.) 1, 4. G. hagni, Sample 549A-24-2,123 cm. 2-3. G. ciperoensis-angustiumbilicata, Sample 549A-11-1, $30 \mathrm{~cm}$. (3) enlargement of Figure 2, scale bar $=10 \mu \mathrm{m}$. 5. G. increbescens, Sample 549A-24-2, 123 cm. 6-9. G. ampliapertura, $(6,9)$ Sample 549A-24-2, $123 \mathrm{~cm}$ (9, latest Eocene), (7-8) Sample 549A-10-6, $40 \mathrm{~cm}$ (8, Oligocene). 10-11. G. tapuriensis, Sample $549 \mathrm{~A}-15-2,80 \mathrm{~cm}$. 12. Globorotalia sp. 2, Sample 549A-15-2, $80 \mathrm{~cm}$. 

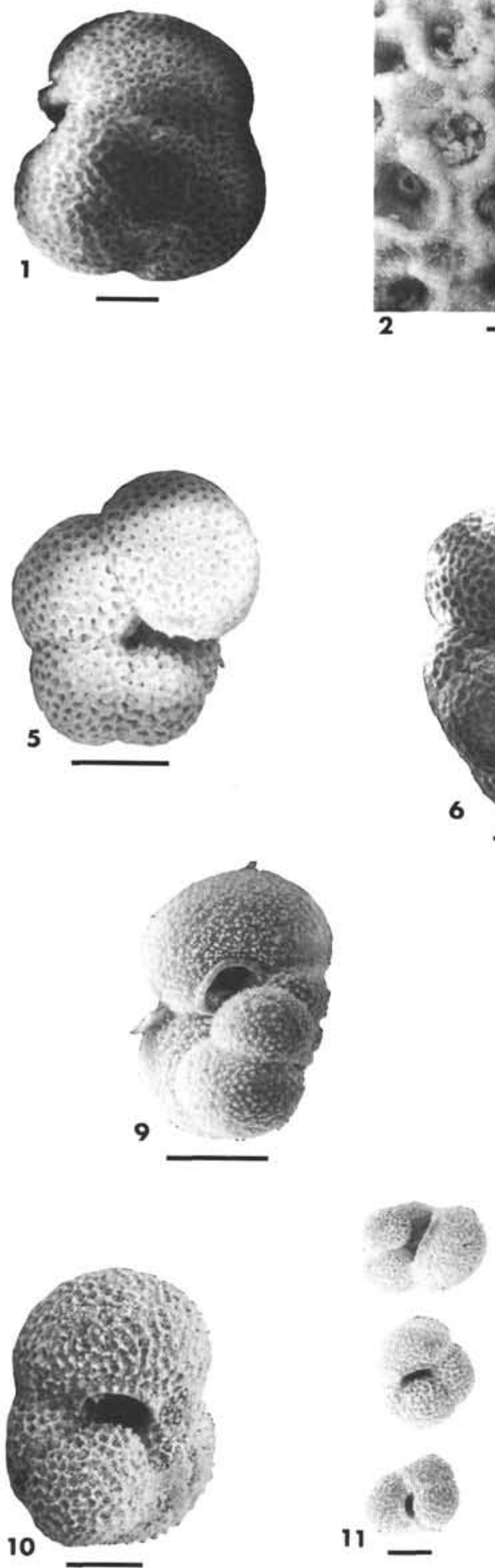

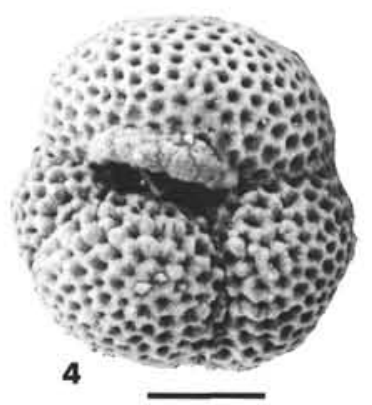

3
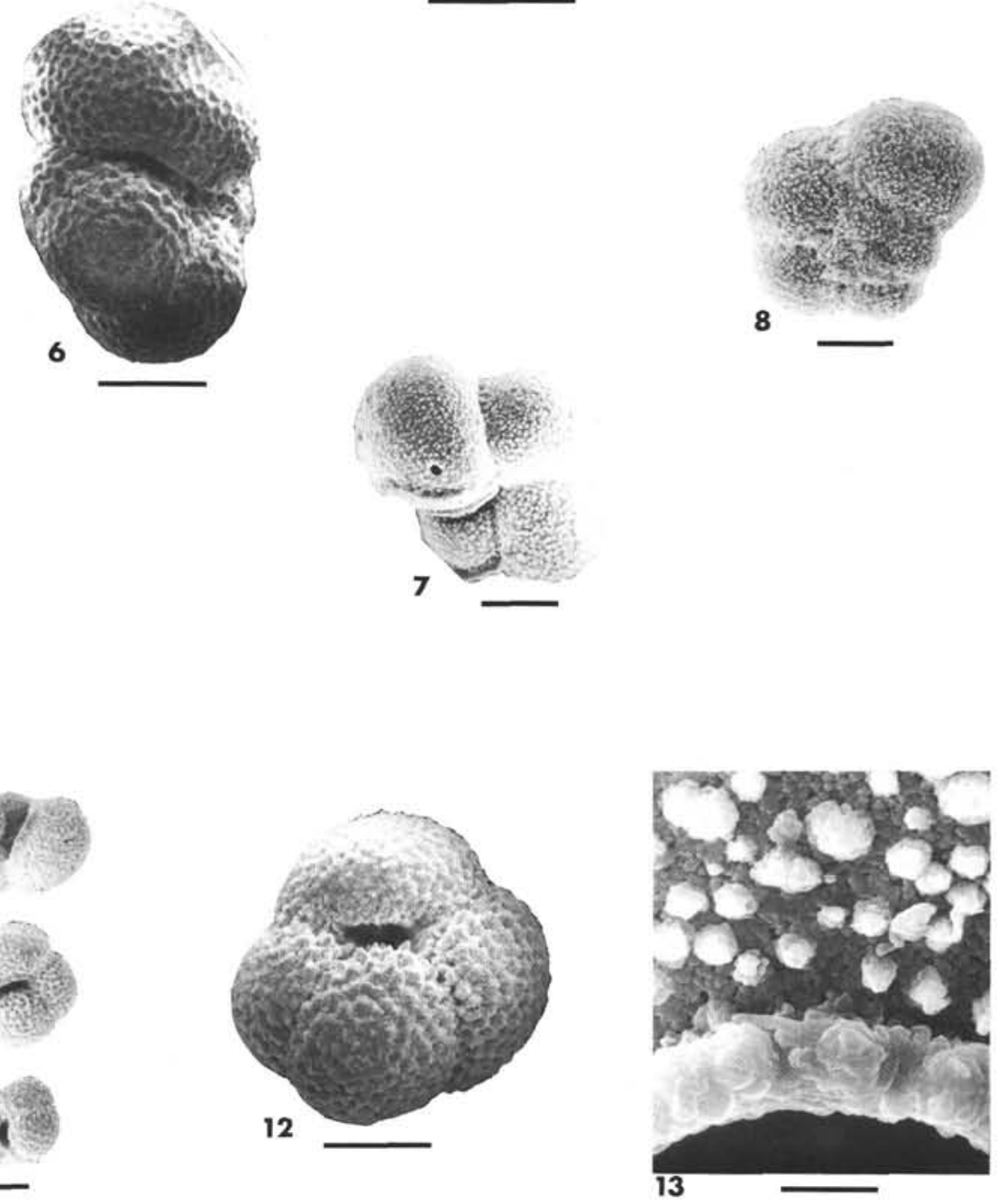

Plate 4. (Scale bars $=100 \mu \mathrm{m}$, unless otherwise indicated.) 1-3. Globorotalia sp. 2, (1) Sample 549A-15-2, 80 cm, (2-3) Sample 549A-24-2, 123 $\mathrm{cm}(2$, texture enlargement, scale $=10 \mu \mathrm{m})$. 4. G. angiporoides, Sample 549A-11-1, $30 \mathrm{~cm}$. 5-6. G. opima opima, (5) Sample 549A-11-1, 30 $\mathrm{cm}$, (6) Sample 549A-10-6, $40 \mathrm{~cm}$. 7-9, 13. G. munda, (7-9) Sample 549A-11-1, 30 cm, (13) Sample 549A-10-6, $40 \mathrm{~cm}$, enlargement along aperture, showing test recrystallization (scale bar $=10 \mu \mathrm{m}$ ). 10-11. G. linaperta, Sample 549A-10-6, $40 \mathrm{~cm}$. 12. G. euaperta, Sample 549A-11-1, $30 \mathrm{~cm}$. 